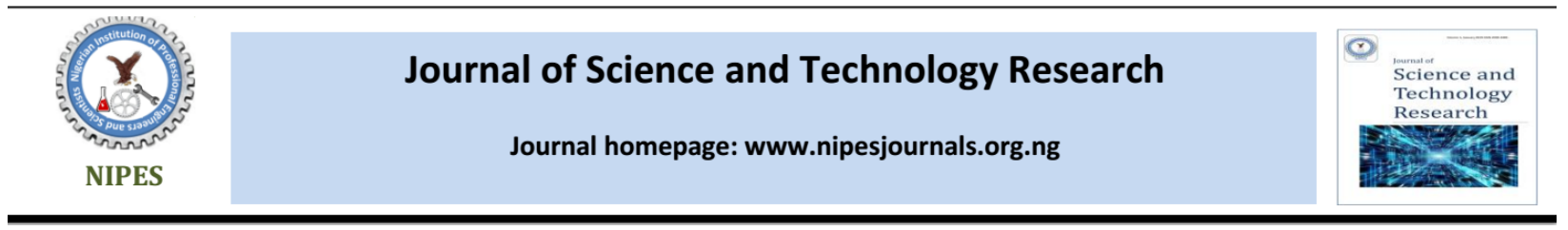

\title{
Bacteriological Quality of Aerial Ambient Air in Selected Creche and Daycare Centers in Ugbowo, Benin City
}

\author{
*1Ologbosere, O.A. and ${ }^{2}$ Ogofure, A.G. \\ ${ }^{1,2}$ Department of Microbiology, Faculty of Life Sciences, University of Benin, Benin City, Nigeria \\ *Corresponding author: oluwabunmi.ologbosere@ uniben.edu
}

\section{Article Info}

Received 01 June 2020

Revised 19 June 2020

Accepted 02 July 2020

Available online 31 August 2020

Keywords:

creche, aycare centers, indoor air, classrooms, antibiogram, public health

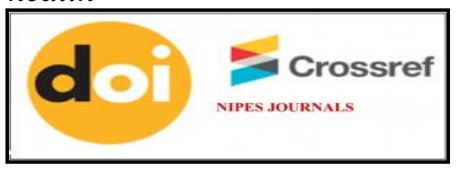

https://doi.org/10.37933/nipes/2.3.202 0.11

https://nipesjournals.org.ng

(c) 2020 NIPES Pub. All rights reserved

\begin{abstract}
This research was conducted to evaluate the bacteriological quality of aerial ambient air in selected creche and daycare centers in Ugbowo, Benin City. Indoor air samples were collected (plates exposed for 30 and 45 minutes) from two daycare centers ( $\mathrm{SCH} A$ and $\mathrm{SCH} B$ ) and subjected to bacteriological analyses. The airborne bacterial burden, characterization, antibiogram and multiple antibiotic resistance (MAR) index were evaluated. Multiple comparisons (Turkey test) were used to analyze collected data. Results revealed significantly higher bacterial count for plates exposed for and $45 \mathrm{~min}$ over $30 \mathrm{~min}$. more so, there was no difference $(P>0.05)$ between plates incubated for $24 \mathrm{~h}$ and $48 \mathrm{~h}$. The bacterial count for ranged between 0.1850 to $0.4444 \times 10^{3} \mathrm{cfu} / \mathrm{m}^{3}$ and 0.3704 to $0.3889 \times 10^{3} \mathrm{cfu} / \mathrm{m}^{3}$ for $\mathrm{SCH} A$ and Sch $B$ respectively. Comparing an enriched with a general purpose medium, bacterial count for Columbia blood agar was significantly $(p<0.05)$ higher than the later. E. coli, Bacillus, Staphylococcus aureus and Pseudomonas were found in the indoor air of SCH A and B classrooms. Following sanitary standards, there were intermediate to high level of contamination for SCH A and B during period of class activities. The antibiogram of the isolates revealed that they were susceptible to gentamicin while resistance was seen in most of the tested antibiotics thus confirming that these isolates were multiresistant. All isolated bacteria were found to have MAR index greater than 0.2. This further connotes that the pathogens were from high sources of contamination and have a public health importance.
\end{abstract}

\section{Introduction}

Crèche or daycare centers are not new terminologies or registers to a working class parents with infant or toddlers. Most of the time, some parents, often choose a suitable crèche on the basis of nearness to their places of work while others may further consider the sanitary condition(s) as well as other factors they may deem necessary. Nonetheless, irrespective of their choices, one thing is certain, which is, the quality of indoor air will eventually have an impact on the health of the child. The quality of health of the indoor air in the daycare centers is directly related to the quality of health of the children (howbeit in the long run). The microbiological quality of the air is a major determinant of the health status of the indoor air and by extension the health of the infants/toddlers 
in the daycare centers. The importance of the air cannot be overemphasized as it is the most important entity for survival because one can barely survive without or when deprived of air for a few minutes [1]. As opined by Douwes et al. [2], air in its dynamic form contains bioaerosols and particulate matters. The levels of the former is a function of several factors such as number and activities of the occupants, structure and nature of building materials, the furnishings as well as the outdoor air cross-ventilating into the building. More so, Hospodsky et al. [3] postulated that the microbial burden of the indoor air is hugely dependent on the persons or individuals (infants and toddlers alike in crèche) in the building. It has also been reported that the microbial burden in the indoor air is mostly due to allochthonous microorganisms whose presence can be related to aerial transport from soil and other reservoirs (including humans) as a function of environmental conditions" [4]. Thus, the microbiological quality of indoor air is an important criterion that must be taken into account when making a choice (for those priceless gifts of children) by parents. This obviously must not only apply to crèche alone but also by extension to schools for the older children, workplaces for parents, etcetera. One of the primary fallouts of poor microbiological indoor air quality is the increase in the probability of contracting respiratory infections (upper or lower) and other health issues related to hypersensitivity disorders [4; 5]. A report by WHO [6] on the number of epidemiological studies showed that, sufficient evidence exists for the association between indoor dampness-related factors (air quality) and a wide range of effects on respiratory health, including respiratory infections, asthma development, asthma exacerbation, as well as development of upper respiratory tract symptoms like cough, wheeze and dyspnea. To this end, this study was designed to evaluate the microbiological quality of the indoor ambient air in selected crèche or daycare centers in Ugbowo metropolis with a focus on isolating bacteria genera implicated in respiratory infections

\section{Methodology}

\subsection{Study Design and Sample Collection}

The selected schools (names withheld; as they were the few that consented for collection of samples) have sections for crèche or daycare centers in addition to nurseries, primary and secondary. Notwithstanding, the focus was on crèche or daycare. Samples were collected in replicates from the selected classrooms. Sampling was done during active class activity (where toddlers were seated in their respective class rooms). Samples were also collected during the early hours of the morning (when there was no class activity). Lastly, sampling was done after the close of school hours. The time variation for collection of samples was 30 minutes and 45 minutes respectively for each sampling successfully carried out. Sampling was carried out in the month of June, 2017.

\subsection{Sampling Procedure}

Bacteria measurement was made using the passive air sampling technique; the settle plate method using 90mm diameter Petri dishes. The sampling height was estimated to human breathing zone which is $1 \mathrm{~m}$ above the floor at the center of the classroom. In a bid to determine the appropriate surface density for enumeration and to determine the microbial load with respect to time of exposure, the sampling time were set at 30 and 45 minutes. Samples were collected thrice for one classroom within the space of two weeks. As stated earlier, sampling was carried out before, during and after class activity. After exposure the samples were taken to the laboratory and incubated at 
$37^{\circ} \mathrm{C}$ for $24 \mathrm{~h}$. for cultivation of bacteria. The total number of colonies were enumerated and converted to organisms per cubic meter of air according to the equation delineated by Omeliansky as cited by Hayleeyesus and Menaye [7].

$$
\frac{\mathrm{CFU}}{m^{3}}=\frac{5 a \times 10000}{b t}
$$

Where: $a=$ number of colonies on Petri plates

$b=$ surface area of the Petri plates in $\mathrm{cm}^{2}$

$t=$ time of exposure

\subsection{Bacteriological Analysis}

Bacteriological analysis was carried out to purify, characterize and identify the bacterial species present in the indoor air environment of crèche of the selected schools. The samples were cultured primarily on the different selective/differential media as well as enriched media and incubated at $37^{\circ} \mathrm{C}$ for $24 \mathrm{~h}$. The isolates were further subjected to biochemical characterization and hemolysis on blood agar (Columbia agar blood base). Suspected isolates were presumptively identified by colony morphology, colour, odour, and haemolysis (Columbia blood agar base). Isolates depending on Gram stain and biochemical characterization were also identified by growth on Oxacillin Resistant screening agar base (ORSAB), Pseudomonas cetrimide agar, Eosine methylene blue agar, Bacillus cereus agar, Mannitol salt agar, Bile esculin agar and Salmonella Shigella agar (all manufactured by Oxoid, Basingstoke, UK) [8].

\subsection{Antibiogram}

The suspected bacterial isolates which were identified using the standard culture based methods were subjected to antibiogram. All bacterial isolates were tested for resistance to sensitivity to different antibiotics using the standard disc manufactured by Oxoid, Basingstoke UK, following the methods of Kirby Bauer disc diffusion test. For the disc diffusion assay, bacteria were grown in tryptic soy broth between 18 and 24 hours and thereafter subcultured on Mueller-Hinton agar after standardization of the culture ( $0.5 \mathrm{McF}$ arland Standard). The inoculum was streaked onto plates of Mueller-Hinton agar using a sterile inoculating loop and impregnated with appropriate antibiotics using a sterile forceps. The results were recorded after $24 \mathrm{~h}$. of incubation at $37^{\circ} \mathrm{C}$. The commercially available antibiotics discs, obtained from Oxoid were used to determine the resistance patterns of the isolates. The diameter of the zone of inhibition around each disc was measured and interpreted as Resistant (R), Intermediate (I) or Sensitive (S) in accordance with the recommended standard established by the Clinical Laboratory Standards Institute [9].

\subsection{Multiple Antibiotic Resistance (MAR) Index}

The MAR index is a good tool for health risk assessment which identifies if the isolates are from a region of high or low antibiotic use. A MAR index of 0.2 and above indicates a 'high-risk' source of contamination [10]. The multiple antibiotic resistance MAR index was determined for each isolate using the methods delineated by Chitanand et al. [11] by dividing the percentage of antibiotic 
resistance of the entire antibiotics used in the study to the total possible number percentage of antibiotics used.

\subsection{Data Collection and Analysis}

After incubation for $24 \mathrm{hrs}$ and $48 \mathrm{hrs}$ on the media used for analyses, replicates of bacteria growth were counted and basic descriptive statistics were employed for possible delineation of the means and standard errors. The differences in microbiological air qualities of the classrooms were evaluated using multiple comparisons (one-way ANOVA) at 0.05 probability level (95\% confidence interval).

\section{Results and Discussion}

Table 1: Total heterotrophic bacteria count of selected crèche in Ugbowo metropolis

\begin{tabular}{|c|c|c|c|c|c|c|}
\hline \multirow{2}{*}{ Sampling Time } & \multirow[b]{2}{*}{$\begin{array}{c}\text { Exposure } \\
\text { time }\end{array}$} & \multirow{2}{*}{ Media } & \multicolumn{2}{|c|}{$\begin{array}{l}\text { Count After } 24 \mathrm{~h} \text {. } \\
\left.\times 10^{3} \mathrm{cfu} / \mathrm{m}^{3}\right)^{\mathrm{ab}}\end{array}$} & \multicolumn{2}{|c|}{$\begin{array}{l}\text { Count After } 48 \mathrm{~h} \text {. } \\
\left.\times 10^{3} \mathrm{cfu} / \mathrm{m}^{3}\right)^{\mathrm{ab}}\end{array}$} \\
\hline & & & $\mathrm{SCH} \mathrm{A}^{\mathrm{ab}}$ & $\mathrm{SCH} \mathrm{B}{ }^{\mathrm{ab}}$ & $\mathrm{SCH} \mathrm{A}^{\mathrm{ab}}$ & $\mathrm{SCH} \mathrm{Bab}$ \\
\hline \multirow{3}{*}{12 noon (during class) } & & $\mathrm{MHA}^{\mathrm{a}}$ & $0.1850^{\mathrm{ab}}$ & $0.3704^{\mathrm{ab}}$ & $0.1879^{a b}$ & $0.3958^{a b}$ \\
\hline & $30 \mathrm{~min}$ & $\mathrm{CBA}^{\mathrm{b}}$ & $0.2037^{\mathrm{ab}}$ & $0.3889^{a b}$ & $0.3518^{a b}$ & $0.4395^{a b}$ \\
\hline & & $\mathrm{MHA}^{\mathrm{a}}$ & $0.4444^{\mathrm{ab}}$ & $0.6543^{\mathrm{ab}}$ & $0.5926^{\mathrm{ab}}$ & $0.7209^{a b}$ \\
\hline \multirow[t]{2}{*}{12 noon (during class) } & $45 \mathrm{~min}$ & $\mathrm{CBA}^{\mathrm{b}}$ & $1.0246^{b}$ & $4.0741^{b}$ & $1.3209^{b}$ & $4.7284^{\mathrm{ab}}$ \\
\hline & & $\mathrm{MHA}^{\mathrm{a}}$ & $0.1716^{a b}$ & $0.1728^{a b}$ & $0.3407^{a b}$ & $0.4296^{a b}$ \\
\hline \multirow[t]{2}{*}{ 7:30 am (before class) } & $30 \mathrm{~min}$ & $\mathrm{CBA}^{\mathrm{b}}$ & $0.1543^{a b}$ & $0.3209^{a b}$ & $0.2996^{a b}$ & $0.5370^{\mathrm{ab}}$ \\
\hline & & $\mathrm{MHA}^{\mathrm{a}}$ & $0.5555^{a b}$ & $0.3703^{a b}$ & $0.7673^{a b}$ & $0.0419^{a b}$ \\
\hline 7:30 am (before class) & $45 \mathrm{~min}$ & $\mathrm{CBA}^{\mathrm{b}}$ & $0.8518^{a b}$ & $0.6748^{a b}$ & $1.0741^{a b}$ & $0.9741^{a b}$ \\
\hline
\end{tabular}

Legend: same alphabets across each row signifies no significant difference $(P<0.05)$

MHA = Mueller Hinton agar

$\mathrm{CBA}=$ Columbia blood agar base supplemented with blood

SCH A = name withheld (20 students)

SCH B = name withheld (22 students) 
A.O. Ologbosere and A.G. Ogofure / NIPES Journal of Science and Technology Research

$$
\text { 2(3) } 2020 \text { pp. 103-112 }
$$

Table 2: Biochemical and cultural morphological characteristics of bacterial isolates from the crèches of $\mathrm{SCH} \mathrm{A}$ and $\mathrm{B}$

\begin{tabular}{|c|c|c|c|c|}
\hline \multicolumn{5}{|l|}{ Cultural } \\
\hline Elevation & Low convex & Low convex & Convex & Low convex \\
\hline Margin & Smooth & Entire & Entire & Smooth \\
\hline Colour & Cream & Light Green & Cream & Cream \\
\hline Shape & Circular & Circular & Circular & Circular \\
\hline \multicolumn{5}{|l|}{ Morphological } \\
\hline Gram stain & Positive & Negative & Negative & Positive \\
\hline Cell type & Cocci & Rod & Rod & Rod \\
\hline Arrangement & Clusters & Single & Single & Short clusters \\
\hline Spore staining & ND & ND & ND & Positive \\
\hline \multicolumn{5}{|l|}{ Biochemical } \\
\hline Coagulase & Positive & ND & ND & ND \\
\hline Catalase & Positive & Positive & Positive & Positive \\
\hline Indole & Negative & Negative & Positive & Negative \\
\hline Citrate & Positive & Positive & Negative & Positive \\
\hline Urease & Positive & Negative & Negative & Negative \\
\hline Oxidase & Negative & Positive & Negative & Negative \\
\hline Glucose & Positive & Negative & Positive & Positive \\
\hline Sucrose & Positive & Negative & Positive & Positive \\
\hline Lactose & Positive & Negative & Positive & Positive \\
\hline Mannitol & Positive & Positive & Positive & Positive \\
\hline Gas formation & Negative & Negative & Positive & Negative \\
\hline $\mathrm{H}_{2} \mathrm{~S}$ formation & Negative & Negative & Negative & Negative \\
\hline \multirow[t]{3}{*}{ Gr. Diff. Agar } & MSA, ORSAB & PCA & $\mathrm{EMB}, \mathrm{MCC}$ & $\mathrm{BCA}$ \\
\hline & Pale yellow colonies & Green colonies & Green metallic sheen & Straw coloured colonies \\
\hline & Light blue colonies & - & Pink colonies & - \\
\hline Identity & Staphylococcus aureus & Pseudomonas sp. & Escherichia coli & Bacillus sp \\
\hline
\end{tabular}

Legend: MSA= Mannitol salt agar, $\mathrm{PCA}=$ Pseudomonas cetrimide agar; $\mathrm{EMB}=$ Eosin methylene blue agar, $\mathrm{SSA}=$ salmonella Shigella agar, $\mathrm{BCA}=$ Bacillus cereus agar, $\mathrm{DCA}=$ Deoxycholate citrate agar, $\mathrm{MCC}=$ MacConkey agar.

The results for the microbiological assessment of indoor air quality in SCH A and SCH B shows the total heterotrophic bacteria count of selected crèche after $24 \mathrm{~h}$ and $48 \mathrm{~h}$ of incubation. Columbia agar blood base had significantly higher bacterial count for plates exposed for $30 \mathrm{~min}$. and $45 \mathrm{~min}$ respectively compared to Mueller Hinton agar plates. Meanwhile there was no significant difference $(P>0.05)$ for cultures incubated for $24 \mathrm{~h}$ and $48 \mathrm{~h}$. respectively (even though there was an increase in cell numbers). The bacterial count ranged between 0.1850 to $0.4444 \times 10^{3} \mathrm{cfu} / \mathrm{m}^{3}$ and 0.3704 to $0.3889 \times 10^{3} \mathrm{cfu} / \mathrm{m}^{3}$ for SCH A and Sch B respectively. The cultural, morphological and biochemical characteristics of bacterial isolates from the crèches of SCH A and SCH B schools revealed the 
A.O. Ologbosere and A.G. Ogofure / NIPES Journal of Science and Technology Research

2(3) 2020 pp. 103-112

presence of E. coli, Bacillus, Staphylococcus aureus and Pseudomonas in the indoor air of the selected crèche classrooms. The evaluation of air quality in the selected crèche classes according to sanitary standards showed that there was intermediate to high level of contamination for periods of class activity in both schools evaluated for the study.

Table 3: Evaluation of air quality in selected crèche classes according to sanitary standards for nonindustrial premises

\begin{tabular}{|c|c|c|c|c|c|c|}
\hline \multirow[b]{3}{*}{ Microbes } & \multirow[b]{3}{*}{ Value Range } & \multirow[b]{3}{*}{ Degree of Pollution } & \multicolumn{2}{|c|}{ Class Activity } & \multicolumn{2}{|c|}{ No Class Activity } \\
\hline & & & $\mathrm{SCH} A$ & $\mathrm{SCH} \mathrm{B}$ & $\mathrm{SCH} A$ & $\mathrm{SCH} \mathrm{B}$ \\
\hline & & & & & & \\
\hline \multirow[t]{5}{*}{ Bacteria } & $<50$ & Very low & - & - & - & - \\
\hline & $25-100$ & low & - & - & - & - \\
\hline & $100-500$ & Intermediate & - & - & + & + \\
\hline & $500-2000$ & High & + & - & - & - \\
\hline & $>2000$ & Very high & - & + & - & - \\
\hline
\end{tabular}

NOTE: $+=$ within range, $-=$ out of range

Table 4: Antibiotics resistance of isolates from indoor air environment in $\mathrm{SCH} \mathrm{A}$ and $\mathrm{B}$ crèche classrooms.

Resistance to antibiotics (\%)

\begin{tabular}{lccccccc} 
Isolates (n) & VA & CRO & CFM & CN & AMP & KZ & AML \\
\hline S. aureus (4) & $4(100)$ & $4(100)$ & $4(100)$ & $0(0)$ & $4(100)$ & $0(0)$ & $2(50)$ \\
E. coli $(2)$ & - & $0(0)$ & $4(100)$ & $0(0)$ & - & $2(50)$ & $2(50)$ \\
$P$. aeruginosa $(2)$ & - & $4(100)$ & $2(50)$ & $0(0)$ & - & $4(100)$ & $2(50)$ \\
Bacillus $(2)$ & - & $4(100)$ & $2(50)$ & $0(0)$ & $4(100)$ & $2(50)$ & $4(100)$ \\
\hline
\end{tabular}

Legend: $\mathrm{VA}^{30}=$ Vancomycin, $\mathrm{CRO}^{30}=$ Ceftriaxone, $\mathrm{CFM}^{5}=$ Cefixime, $\mathrm{CN}^{10}=$ Gentamycin, $\mathrm{AMP}=$ Ampicillin, $\mathrm{KZ}^{30}=$ Cephazolin, $\mathrm{AML}^{20}=$ Amoxycillin. Superscripts are the concentration of antibiotics in dics. 


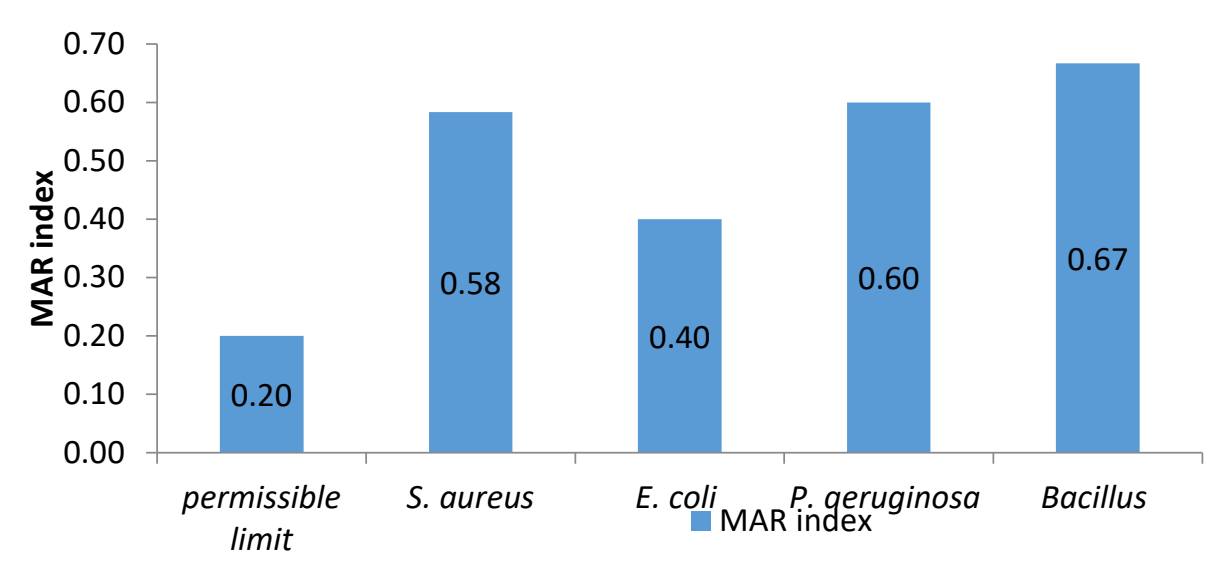

Figure 1: Multiple Antibiotics Resistance Index of Isolated bacterial pathogens.

The antibiogram of the isolates revealed that they were sensitive to gentamicin while resistance was seen in most of the tested antibiotics thus confirming that these isolates were multiresistant. All isolated bacterial pathogens were found to have MAR index greater than 0.2 rated as the normal permissible range or limit. This further connotes that the pathogens were from high sources of contamination and have a public health importance.

The bacteriological quality assessment of indoor air study is one of the most vital investigations to determine the microbial indoor air pollution. The information on indoor microbial concentrations of airborne bacteria (as well as fungi) is necessary to estimate both the health hazard and to create standards for indoor air quality control. The present study demonstrated the concentration of culturable bacterial isolates from two separate locations (SCH A and SCH B crèche) (Table 1). A fundamental understanding of the microbial community in the indoor air environment, including estimates of diversity, function, and concentration, is necessary to develop an accurate portrayal of human exposure and to inform the design and operation of buildings to improve human health [12]. The concentration of bacterial aerosols in the indoor air environment as sampled in this study evaluated using the settle plate method ranged between $0.0185-4.0741 \times 10^{3} \mathrm{CFU} / \mathrm{m}^{3}$ for heterotrophic bacterial. There was a significant difference $(P<0.05)$ in the concentration or number of bacterial species recovered from Columbia agar blood base compared to Mueller Hinton agar (Table 1). This may largely be due to the fact that the former being an enriched media is able to cultivate both fastidious and non-fastidious bacteria even if they are present in low concentration. More so, there was no significant difference $(P>0.05)$ in the concentration of bacteria present in the indoor air for both schools (crèche) sections evaluated in the study. This could be attributed to the fact that the density of human population is almost similar as there are ranges for class registration (in order to curb overcrowding of classes). While this reason is laudable, it must be of note that the number (quantity) of bacteria present in the indoor air is vital for initiation of infection as much as the pedigree of the bacteria. There was also no significant difference $(P>0.05)$ observed between the population density of indoor air environment during class activity and when there was no class activity (Table 1). A number of factors could be responsible for the above findings and these include 
the sampling time between the end of class activities and sample collection (which in this case was about 12 hours), the structural design cum quality of the building (which could give an insight to the level of ventilation and cross ventilation experienced in the supposed school classrooms) and lastly, the contamination level of the surrounding outdoor air cross-ventilating into the school premises. In this study, it was crystal clear that more bacterial colonies were recovered from Columbia blood agar compared to Mueller Hinton agar (Table 1). This could be attributed to the blood enrichment on the Columbia blood agar base, added to the fact that it contains special peptone in its constituent compared to beef extract in Mueller Hinton agar. The special peptone along with other constituents makes it a multi-purpose medium suitable for the cultivation of fastidious organisms as well as other non-fastidious organisms [8]. The bacterial count was higher during class activities in the afternoon compared to the morning session without any class activity (Table 1). This further strengthens the point that human activities play a key role in determining the burden of microorganism in the indoor air environment [3]. The findings in this study is in consonance with the report of Shahida et al.[13], who monitored the indoor microbiological air quality of different daycare centers and reported intermediate to very high degree of contamination as counts were above $500 \mathrm{cfu} / \mathrm{m}^{3}$ (within the range of $730-3330 \mathrm{cfu} / \mathrm{m}^{3}$ ). Similarly, several reports of intermediate to high contamination of indoor air qualities can also be found in the reports of Bragoszewska and Patuszka [14], who evaluated the bacterial aerosol potential in nursery schools in Poland. More so, several other reports about the microbiological quality of indoor air in homes [15], hospital wards [5] and libraries [7] were found to have consistent results with the reports in this study (with majority of the indoor air samples collected having intermediate level of contamination). The microbial isolates characterized and identified include Staphylococcus aureus, Pseudomonas aeruginosa, Bacillus sp., and Escherichia coli (Table 2). Ogofure et al. [16] opined that microbes are not just ubiquitous in nature but a plethora of their activities in the environment can lead to positive or negative consequences on humans, animals and plants. Therefore, most airborne pathogenic bacterial species usually originates or stem from water, food, human or animal sources since air do not have the necessary nutrient to sustain bacteria for a long time. Airborne transmissions of $S$. aureus, $P$. aeruginosa and $E$. coli as well as other isolated bacteria seem important in the acquisition of nasal carriage, and/or spread of the organism on skin scales that are liberated into the air during daily activities [17]. The isolated bacteria (Table 2) were found to be of public health significance or importance because they were resistant to more than two different classes of antibiotics which further complicate the situation and the wellbeing of the toddlers in the daycare centers in general (Table 3). When the level of contamination is low, there may be no need to worry, but with high level of contamination during class activity, it calls for concern (Table 4). All bacteria isolates were found to be susceptible to gentamicin while resistance was found vancomycin, amoxicillin and cefixime amongst others (Table 4). The isolates in this research had a multiple antibiotics resistance index above 0.2 (Figure 1). According to Mishra et al. [18], multiple Antibiotics Resistance (MAR) index of 0.2 or higher indicates high risk sources of contamination, MAR index of 0.4 or higher is associated with human faecal source of contamination (Figure 1). Similar reports were obtained in the susceptibility of bacteria isolated from surfaces where they were all found to be greater than 0.2 indicating and confirming the problem of antibiotic resistance $[16 ; 19 ; 20]$. 
A.O. Ologbosere and A.G. Ogofure / NIPES Journal of Science and Technology Research

2(3) 2020 pp. 103-112

\section{Conclusion}

The indoor air quality of the two day care centers ( $\mathrm{SCH}$ A and B) evaluated in this study showed that the classrooms of toddlers harbor pathogens of public health importance. Their presence and concentration in the indoor air environment is worrisome as it could pose a problem for the child whose immune system is underdeveloped or a child with compromised immune system. Before you take your child to that crèche or day care ensure the place is properly ventilated and there most likely won't be any form of poor indoor air quality.

\section{References}

[1] M. Radojevic and V.N. Bashkin (2007). Practical Environmental Chemistry. The Royal Society of Chemistry, London, UK.

[2] J. Douwes, P. Thorne, N. Pearce and D. Heederik (2003). Bioaerosol health effects and exposure assessment: progress and prospects. Annals of Occupational Hygiene vol. 47(3): 187-200.

[3] D. Hospodsky, J. Qian, W. W. Nazaroff, N. Yamamoto, K. Bibby and H. Rismani-Yazdi (2012). Human occupancy as a source of indoor airborne bacteria. PLoS One vol. 7: e34867

[4] R. L. Gorny, T. Reponen, K. Willeke, D. Schmechel, E. Robine, M. Boissier and S.A. Grinshpun (2002). Fungal fragments as indoor air biocontaminants. Applied and Environmental Microbiology vol. 68(7):35223531.

[5] F. O. Ekhaise and I.B. Ogboghodo (2011). Microbiological Indoor and Outdoor Air Quality of Two Major Hospitals in Benin City, Nigeria. Sierra Leone Journal of Biomedical Research vol. 3(3): 169-174.

[6] World Health Organisation. (2009). Who Guidelines for Indoor Air Quality: Dampness and Mould. WHO Copenhagen, Denmark.

[7] F. S. Hayleeyesus and A. M. Manaye (2014). Microbiological Quality of Indoor Air in University Libraries. Asian Pacific Journal of Tropical Biomedicine vol. 4(1): S312-S317

[8] E.Y. Bridson (2006). The Oxoid Manual ( $9^{\text {th }}$ Edition). Oxoid Limited, Basingstoke Hamsphire, England 623 pp.

[9] Clinical Laboratory Standard Institute (CLSI) (2017). Performance Standards for Antimicrobial Susceptibility Testing (27th ed.). CLSI supplement M100S. Wayne, Pennsylvania $250 \mathrm{pp}$.

[10]R. Davis and P.D. Brown (2016). Multiple antibiotic resistance index, fitness and virulence potential in respiratory Pseudomonas aeruginosa from Jamaica. Journal of Medical Microbiology vol. 65: 261-271.

[11] M.P. Chitanand, T.A. Kadam, G. Gyananath, N.D. Totewad and D.K. Balhal (2010). Multiple antibiotic resistance indexing of coliforms to identify high-risk contamination sites in aquatic environment. Indian Journal of Microbiology vol. 50: 216-220

[12]J.P.S. Cabral (2010). Water Microbiology: Bacterial Pathogens and Water. International Journal of Environmental Research and Public Health vol. 7(10):3657-3703.

[13] N. Shahidah, S. Hasnah, S. Shuhaili, A. Syamzany and M.A. Mohd Shukri (2017). Indoor airborne bacteria and fungi at different background area in nurseries and daycare centres environments. Journal CleanWAS. Vol. 1(1): 35-38

[14]E. M. A. Bragoszewska and J. S. Pastuszka (2016). Bacterial aerosols in an urban nursery school in Gliwice, Poland: A case study. Aerobiologia vol. 32: 469-480.

[15]Z. Fang, C. Gong, Z. Ouyang, P. Liu, L. Sun and X. Wang (2014). Characteristic and concentration distribution of culturable airborne bacteria in residential environments in Beijing, China. Aerosol and Air Quality Research vol. 14: 943-953.

[16] A.G. Ogofure, O. I. Bello-Osagie, U.B. Aduba, V.E. Ighodaro, A.O. Emoghene (2018). Qualitative Detection and Isolation of Bacteria from Surfaces of Canned Drinks Sold in Ugbor, Benin City. Annals of Science and Technology Vol 3 (2): 20-25.

[17] Solberg, C.O. (2000). Spread of Staphylococcus aureus in hospitals: causes and prevention. Scandinavian Journal of Infectious Diseases vol. 32:587-595.

[18] M. Mishra, A. K. Patel and N. Behera (2013). Prevalence of multidrug resistant E. coli in the River Mahanadi of Sambalpur. Current on Research Microbiology and Biotechnology vol. 1(5): 239-244.

[19] A.G. Ogofure, J.Z. Saidu,, P.G. Olannye, C.O. Ahonsi and A.O. Emoghene (2019). Quantitative Detection of Methicillin Resistant Staphylococcus aureus from the Surfaces of Canned Drinks Sold in University of Benin 
A.O. Ologbosere and A.G. Ogofure / NIPES Journal of Science and Technology Research

$$
\text { 2(3) } 2020 \text { pp. 103-112 }
$$

Shopping Complexes. Nigerian Research Journal of Engineering and Environmental Sciences vol. 4(1): 227 235

[20]F. O. Ekhaise, E. E. Isitor, O. Idehen and O. A. Emoghene (2010). Airborne microflora in the atmosphere of a hospital environment of University of Benin Teaching Hospital (UBTH), Benin City, Nigeria. World Journal Agricultural Science vol. 6(2):166-170.

\section{Appendix A}

\begin{tabular}{|l|r|}
\hline Parameters & MAR index \\
\hline permissible limit & 0.20 \\
\hline S. aureus & 0.58 \\
\hline E. coli & 0.40 \\
\hline P. aeruginosa & 0.60 \\
\hline Bacillus & 0.67 \\
\hline
\end{tabular}

